\title{
High-Density Polyethylene Composites Filled with Nanosilica Containing Immobilized Nanosilver or Nanocopper: Thermal, Mechanical, and Bactericidal Properties and Morphology and Interphase Characterization
}

\author{
Regina Jeziórska, ${ }^{1}$ Maria Zielecka, ${ }^{1}$ Beata Gutarowska, ${ }^{2}$ and Zofia Żakowska ${ }^{2}$ \\ ${ }^{1}$ Department of Polymer Technology and Processing, Industrial Chemistry Research Institute, Rydygiera 8, 01-793 Warsaw, Poland \\ ${ }^{2}$ Technical University of Lodz, Wolczanska 171/173, 90-924 Lodz, Poland
}

Correspondence should be addressed to Regina Jeziórska; regina.jeziorska-dn@ichp.pl

Received 4 September 2013; Accepted 25 March 2014; Published 7 May 2014

Academic Editor: Nanda Gopal Sahoo

Copyright (C) 2014 Regina Jeziórska et al. This is an open access article distributed under the Creative Commons Attribution License, which permits unrestricted use, distribution, and reproduction in any medium, provided the original work is properly cited.

\begin{abstract}
Silica containing immobilized nanosilver $\left(\mathrm{Ag}-\mathrm{SiO}_{2}\right)$ or nanocopper $\left(\mathrm{Cu}-\mathrm{SiO}_{2}\right)$ was used as a filler for high-density polyethylene (HDPE). The HDPE/Ag-SiO 2 and $\mathrm{HDPE} / \mathrm{Cu}-\mathrm{SiO}_{2}$ composites were prepared by melt blending and injection molding. The microstructure of the composites was examined using transmission electron microscopy (TEM). The crystallization behavior and thermal properties were studied using differential scanning calorimetry (DSC) and thermogravimetry (TGA). The mechanical properties were characterized by tensile, flexural, and impact tests as well as dynamic mechanical thermal analysis (DMTA). The ability of silica to give antimicrobial activity to HDPE was also investigated and discussed. The TEM images indicate that $\mathrm{Ag}-\mathrm{SiO}_{2}$ show lower degree of agglomeration than $\mathrm{Cu}-\mathrm{SiO}_{2}$ nanoparticles. The crystallization temperature increased, whereas crystallinity decreased in the composites. The thermal stability of the composites was significantly better compared to HDPE. Improved stiffness indicating very good interfacial adhesion was observed. Excellent activity against different kinds of bacteria was found.
\end{abstract}

\section{Introduction}

There are numerous ways by which bactericidal properties can be given to a polymer matrix: incorporation of volatile or nonvolatile bactericidal agents directly into polymers $[1$, 2], coating or adsorbing agents onto polymer surfaces [3], immobilization of them to polymers by ion or covalent linkages [4], and the use of polymers that are inherently bactericidal [5]. The antimicrobial activity of silver and copper is well established, especially when metals are applied in the form of nanoparticles (NPs). Silver and copper NPs have strong inhibiting and antimicrobial effects as well as broad spectrum of biocidal activities [6-8]. However, the mechanism of antibacterial effect of silver or copper is still not fully understood. It is generally believed that interactions of silver or copper with thiol groups play the essential role in deterioration of bacteria $[9,10]$. Nanoparticles of these metals are a new group of bactericidal materials due to the different physicochemical properties as compared to the bulk materials of the same composition. The bactericidal efficiency of these metals increases with decreasing their particle size due to their larger specific area. Based on the results of TEM analysis and bactericidal effects of silver and copper nanoparticles it can be stated that nanoparticles of these metals interact with the elements of bacterial membrane resulting in the structural changes leading to the cell death. Moreover, when silver or copper nanoparticles are small enough to disrupt the bacterial cell membranes they can gain entry in order to disrupt the enzyme function [11, 12]. The agglomeration of silver or copper NPs or colloids can result in the decrease in their bactericidal and fungicidal properties.

The problem of NPs stability was solved by the development of silica nanospheres containing immobilized silver or copper NPs [13]. Because of these unique properties, 
their incorporation into different materials often leads to the generation of materials showing activity against a broad spectrum of microbes. Besides polyolefins [2], many other polymers, for example, polyamides [4, 14], polyurethanes [14], silicone rubber [15], and methacrylate copolymers [16], were filled or coated with silver nanoparticles. In all cases a good activity against different kinds of bacteria was found.

In the previous work [17], it was found that silica containing immobilized nanosilver $\left(\mathrm{Ag}-\mathrm{SiO}_{2}\right)$ in the presence of maleated high-density polyethylene improved adhesion between the HDPE and wood fiber. Moreover, silica nanoparticles increased tensile and flexural moduli of wood-filled HDPE composites, pointing to a synergetic effect arising from the presence of the reinforced HDPE phase, containing high amounts of the finely dispersed wood fiber. Improved bactericidal properties against Escherichia coli, Staphylococcus aureus, or Salmonella typhimurium of the wood-filled HDPE composites modified by silica containing immobilized nanosilver were observed.

In the first part of the paper, sol-gel process for manufacturing of nanosilica containing immobilized nanosilver or nanocopper is described. Photon correlation spectroscopy (PCS) analysis, as well as scanning electron microscopy (SEM) and powder X-ray diffraction (XRD), was used to verify the silica size and its surface modification by the added nanosilver or nanocopper. Then, the manufacturing of silica-filled HDPE composites is presented. In the second part of the work, the phase behavior, microstructure, and mechanical properties of silica-filled high-density polyethylene composites were studied using transmission electron microscopy (TEM), differential scanning calorimetry (DSC), thermogravimetry (TGA), and dynamic mechanical analysis (DMTA). Finally, the ability of spherical silica containing immobilized nanosilver or nanocopper to give bactericidal properties to HDPE composites was investigated by the adenosine $-5^{\prime}$-triphosphate (ATP) method and discussed. The purpose of the development of these HDPE composite materials is to make the use of them for a variety of applications possible, which include food packaging, medical devices (e.g., tracheotomy tubes, vascular or urinary catheters, hip prosthetics), healthcare (including disposables), personal care products, fishing nets, vials, and shower mats. The use of spherical silica containing immobilized nanosilver or nanocopper assures long-term bactericidal activity as well as enhanced mechanical properties.

\section{Experimental}

2.1. Materials. The high-density polyethylene (HDPE, Hostalen GC 7260) with the melt flow rate (MFR) of $8 \mathrm{~g} / 10 \mathrm{~min}$ (ISO 1133) was supplied by Orlen Polyolefins (Poland) and used as a base polymeric matrix. Tetraethoxysilane (TEOS) - technical grade, commercial product TES 28 supplied by Wacker Chemie (Germany), ethyl alcoholreagent grade, aqueous ammonia-reagent grade, silver nitrate, copper acetate all supplied by POCh S.A. (Poland), were used as received.

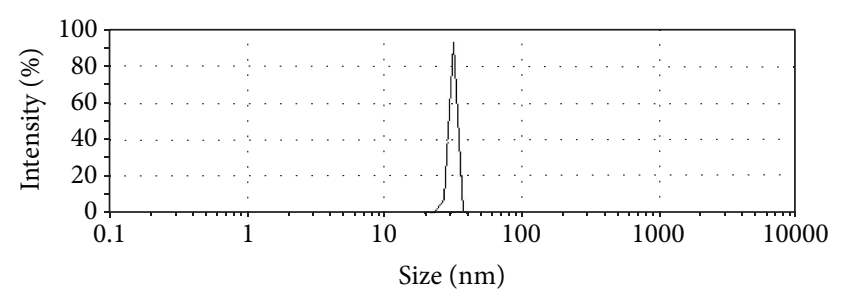

(a)

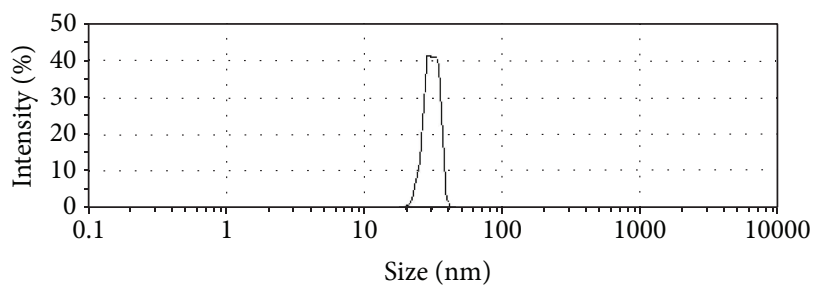

(b)

Figure 1: Particle size distribution curves of $\mathrm{Ag}-\mathrm{SiO}_{2}$ (a) and $\mathrm{Cu}-$ $\mathrm{SiO}_{2}$ (b); average particle size $30 \mathrm{~nm}$.

\subsection{Synthesis of Spherical Silica Containing Immobilized} Nanosilver $\left(\mathrm{Ag}_{-} \mathrm{SiO}_{2}\right)$ or Nanocopper $\left(\mathrm{Cu}-\mathrm{SiO}{ }_{2}\right)$ via Sol-Gel Method. Spherical silica containing immobilized nanosilver $\left(\mathrm{Ag}-\mathrm{SiO}_{2}\right)$ or nanocopper $\left(\mathrm{Cu}-\mathrm{SiO}_{2}\right)$ was synthesized according to the developed sol-gel process $[18,19]$. Ethyl alcohol, aqueous ammonia, and distilled water were mixed to obtain the reaction mixture. The initial $\mathrm{pH}$ of the reaction mixture was measured using pH-meter Schott Instruments LAB 850. All syntheses were carried out at room temperature (293 K). Tetraethoxysilane, distilled immediately before use in the preparation of nanoparticles, used as alkoxysilane precursor was added to the reaction mixture stirred with constant speed during 2 hours. The reaction mixture containing TEOS/EtOH/ $\mathrm{H}_{2} \mathrm{O}$ in the molar ratios $0.023 / 0.500 / 0.477$ was used in the synthesis with the initial $\mathrm{pH}$ range from 10.4 to 11.3 and the final $\mathrm{pH}$ range was 7.5-10.8, with further in situ modification with silver or copper nanoparticles using silver nitrate or copper acetate. The product obtained, nanosilica containing immobilized nanosilver or nanocopper, was dried in an oven dryer for 2 hours at $50-90^{\circ} \mathrm{C}$ or in a spray dryer.

2.3. Nanosilica Characterization. Photon correlation spectroscopy (PCS) was used to evaluate particle size and particle size distribution of resulting sols. The measurements were performed using a Malvern apparatus (Zetasizer Nano ZS). The results were registered in the form of the particle size distribution curve. The resulting peak was analyzed using the averaged number method. In Figure 1 the particle size distribution curves of the nanosilica containing immobilized nanosilver or nanocoper are shown. The developed synthesis method allows obtaining silica nanoparticles characterized by an almost uniform particle size, which is relating to the selection of the sol-gel process parameters. The monomodal particle size distribution and very low dispersion of particle size were observed for homogeneous sols obtained by solgel process. The characteristics of nanosilver or nanocopper 


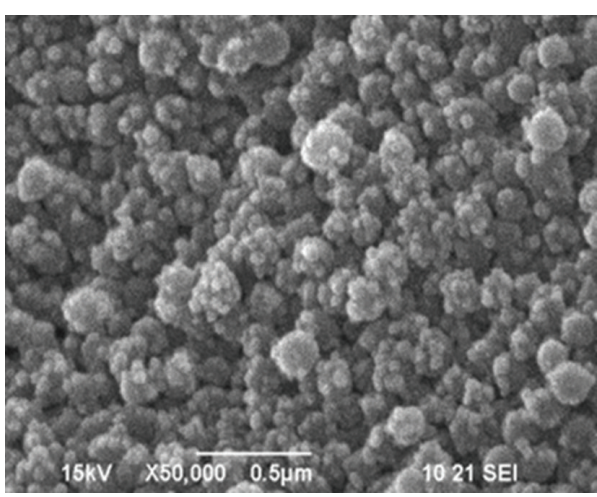

(a)

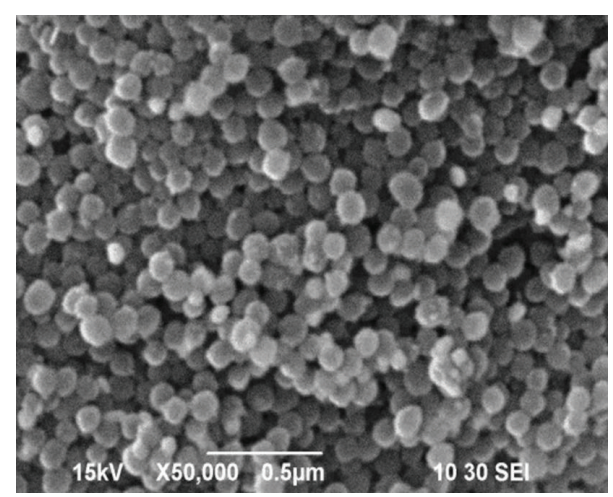

(b)

FIGURE 2: SEM images of the silica containing immobilized: nanosilver (a) and nanocopper (b).

immobilized on nanosilica fillers are presented in Table 1. The specific surface area of silica nanoparticles was measured by BET- $\mathrm{N}_{2}$ sorption method using Gemini 2370 V3.02 apparatus. The results are reported in Table 1 . The size of specific surface area decreased with increasing $\mathrm{pH}$ value of reaction mixture in the sol-gel process. Very good correlation among the specific surface area of silica nanospheres, particle size of sol particles, and the $\mathrm{pH}$ value of the reaction mixture in the solgel process was demonstrated [20]. Silver or copper content was determined by absorption atomic spectroscopy (AAS), using an AAS Spectrometer 5100 PC, Perkin Elmer. The measured silver or copper contents are presented in Table 1. Scanning electron microscopy (SEM) was performed using a JEOL JSM-6490LV operating in the high vacuum mode at accelerating voltage of $15 \mathrm{kV}$ to compare morphology of silica nanoparticles containing immobilized nanosilver ( Ag$\left.\mathrm{SiO}_{2}\right)$ or nanocopper $\left(\mathrm{Cu}-\mathrm{SiO}_{2}\right)$. The micrographs reported in Figure 2 highlight structural similarity of both nanosilica types containing immobilized nanosilver or nanocopper. As can be expected the spherical shape of silica particles is kept and nanoparticles of silver or copper permanently embedded on the nanosilica surface can be observed. The presence of silver or copper at different oxidation levels was confirmed by powder X-ray diffraction using X-ray powder diffractometer Siemens D500 with high-resolution solid-state detector $\mathrm{Si}[\mathrm{Li}]$, copper lamp (operating parameters $U=40 \mathrm{kV}, I=$ $30 \mathrm{~mA})$, and radiation $\mathrm{CuK}(\lambda=0.1541837 \mathrm{~nm})$. Selected XRD curves of silica nanoparticles containing immobilized nanosilver or nanocopper are shown in Figures 3(a) and 3(b), respectively. The layout of the diffraction peaks 110, 200, 220, and 311 is characteristic for the type F cubic structure formed by metallic silver $\mathrm{Ag}^{0}$ or copper $\mathrm{Cu}^{0}$. The angular positions of characteristic reflexes from $\mathrm{Ag}^{0}$ and $\mathrm{Cu}^{0}$ are presented in Table 2. Strongly defined sharp peaks suggest the presence of metallic silver or metallic copper nanoparticles.

2.4. Nanocomposite Preparation. High-density polyethylene and nanosilica were melt mixed using a Berstorff ZE $25 A \times$ $51 D$ twin screw corotating extruder $(D=25 \mathrm{~mm}, L / D=51)$ according to the process published elsewhere [21]. All the
TABLE 1: Characteristics of nanosilica containing immobilized nanosilver or nanocopper.

\begin{tabular}{lcc}
\hline Property & $\mathrm{Ag}-\mathrm{SiO}_{2}$ & $\mathrm{Cu}-\mathrm{SiO}_{2}$ \\
\hline Size $(\mathrm{nm})$ & 30 & 30 \\
Specific surface area $\left(\mathrm{m}^{2} / \mathrm{g}\right)$ & 274.4 & 274.4 \\
Polydispersity (\%) & 0.16 & 0.16 \\
Silver content (ppm) & 70000 & 78000 \\
Silver size $(\mathrm{nm})$ & $7.5-8.0$ & $7.5-8.0$ \\
\hline
\end{tabular}

materials were fed into the throat of the extruder using separate gravimetric feeders. Different screw elements along the screw worked in order to induce polymer melting and achieve a finer dispersion of the nanoparticles in the polymer melt [22]. The three mixing sections enhanced the compounding and also increased the residence time of the mixture in the barrel. The extruder also had a vacuum degassing port to remove any moisture traces or other volatile products formed during compounding. Melt mixing was carried out using a screw speed of $600 \mathrm{rpm}$ and also a temperature profile of 30 , $175,175,180,180,180,180,180,180,180,180,180$, and $180^{\circ} \mathrm{C}$ for the sequential heating zones, from the hopper to the die. The melt temperature and pressure were continuously recorded during compounding. After compounding, the material was extruded from the die, which had two cylindrical nozzles of $4 \mathrm{~mm}$ diameter, and then cooled rapidly in the air and pelletized with an adjustable rotating knife into $4 \mathrm{~mm}$ pellets.

2.5. Structural Properties of Composites. Cross-fracture surfaces of the composites were studied by means of scanningtransmission electron microscope STEM Hitachi S-5500 equipped with a dark-field detector and a bright-field detector.

2.6. Thermal Properties. A Perkin Elmer differential scanning calorimeter (DSC-7) was used for thermal analyses. All experiments were run at the heating rate of $10^{\circ} \mathrm{C} / \mathrm{min}$ under a nitrogen atmosphere. A thermogravimetric analyzer (TGA/SDTA 851e Mettler Toledo) was used to investigate 


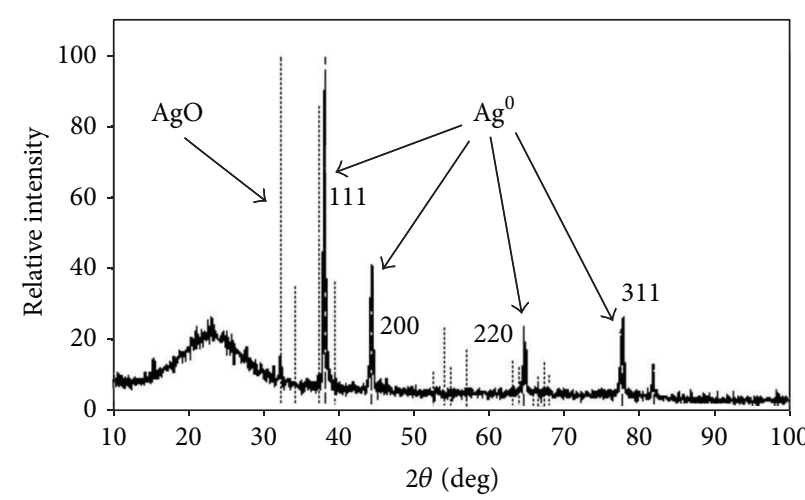

(a)

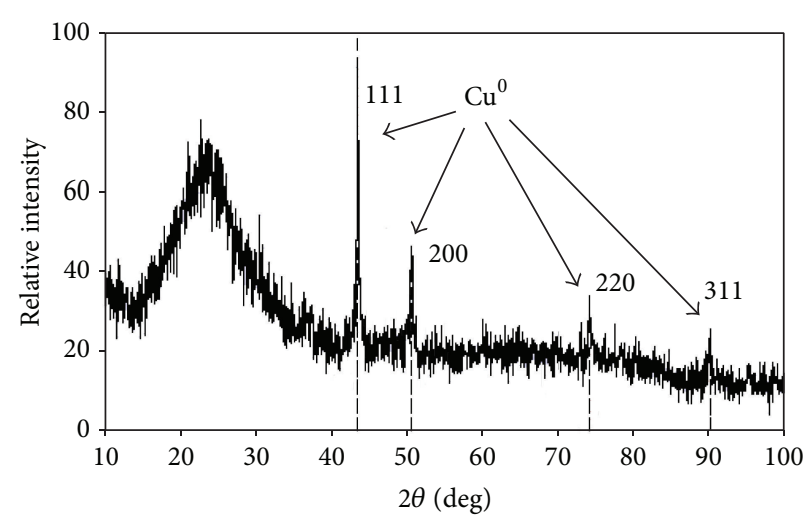

(b)

FIGURE 3: XRD curves of silica containing immobilized nanosilver (a) and nanocopper (b).

TABLE 2: XRD results: the angular position of characteristic reflexes for silica containing immobilized nanosilver or nanocopper.

\begin{tabular}{lcc}
\hline \multirow{2}{*}{ Characteristic reflex } & \multicolumn{2}{c}{ The angular position $(\mathrm{eV})$} \\
& $\mathrm{Ag}$ & $\mathrm{Cu}$ \\
\hline 111 & 38.15 & 43.33 \\
200 & 44.32 & 50.48 \\
220 & 64.49 & 74.20 \\
311 & 77.55 & 90.03 \\
\hline
\end{tabular}

the thermooxidative stability of neat HDPE and the composites. The samples were heated from room temperature to $600^{\circ} \mathrm{C}$ at the heating rate of $10^{\circ} \mathrm{C} / \mathrm{min}$ in the atmosphere.

2.7. Dynamic Mechanical Analysis (DMTA). The dynamic mechanical properties of samples were tested using a dynamic mechanical analyzer, model Rheometrics RDS 2. The torsion method was used with a frequency of $1 \mathrm{~Hz}$, a strain level of $0.1 \%$ in the temperature range of -150 to $100^{\circ} \mathrm{C}$. The heating rate was $3^{\circ} \mathrm{C} / \mathrm{min}$. The testing was performed using rectangular bars measuring approximately $38 \times 10 \times$ $2 \mathrm{~mm}$, prepared by injection molding.

2.8. Mechanical Properties. Samples were prepared by injection molding using an Arburg $420 \mathrm{M}$ single screw injection machine (Allrounder 1000-250) containing five different heating zones. The temperatures of these were $180 / 190 / 195 / 195 / 200^{\circ} \mathrm{C}$, from the feeding zone to the die, while the mold was cooled with water at $25^{\circ} \mathrm{C}$. A minimum of 5 specimens for each composite were tested in order to estimate the precision of the reported data. An Instron Series 4505 tensile tester, which operated at a crosshead speed of $5 \mathrm{~mm} / \mathrm{min}$ at room temperature, was used to measure the tensile and flexural properties of the composites according to ISO 527 and ISO 178, respectively.

2.9. Bactericidal Properties. Escherichia coli strain ATCC 8739, Staphylococcus aureus strain ATCC 6538, Salmonella typhimurium strain ATCC 14028, Pseudomonas fluorescens, and Burkholderia cepacia strains isolated from a fridge's sink were used as test organisms to check bactericidal properties of HDPE and its composites filled with nanosilica containing immobilized nanosilver or nanocopper. The bacteria were grown over $24 \mathrm{~h}$ in trypton-soya medium (TSB, Merck) at $37 \pm 1^{\circ} \mathrm{C}$. The resulting suspension of bacteria was diluted to a concentration of about $1 \times 10^{6} \mathrm{CFU} / \mathrm{mL}$, where CFU is a colony forming unit (this being the measure of viable bacteria). The exact initial concentration of bacteria was determined using the microscopy method. The vitality of bacteria on polymer surface was determined using the adenosine- $5^{\prime}$ triphosphate (ATP) method. The HY-LiTE (Merck) system based on the bioluminescent method was applied to measure the ATP content on polymer surface. Measurement of ATP indicates the current amount of biological material by measuring the emission of light quanta during ATP hydrolysis and the numeric value is called relative light unit (RLU). The polymers, after being taken out from the nutrient medium, were washed three times with deionized distilled water to remove nonadhered cells. Then the samples (in the form of smear) were taken using HY-LiTE test-tube according to producer procedure. They were placed in luminometer (Merck) and RLU values were read. The results were given in $\mathrm{RLU} / \mathrm{cm}^{2}$. The ATP contents on the surfaces of neat polymers placed formerly in the nutrient medium (without bacteria culture) were also determined, as control samples, according to the same procedure. The level of ATP in control samples was 20-39 RLU and it was taken into account in calculations.

\section{Results and Discussion}

3.1. Microstructure of the Silica-Filled HDPE Composites. Filler dispersion and adhesion to the polymer matrix are of great importance for improving the mechanical properties of composites. Good control of the interface morphology of composites is one of the most critical parameters to impart the desired mechanical properties to such materials.

In general, good dispersion of inorganic nanofillers in polymer matrices is especially hard to achieve by melt compounding at high filler content [23]. It is well known 


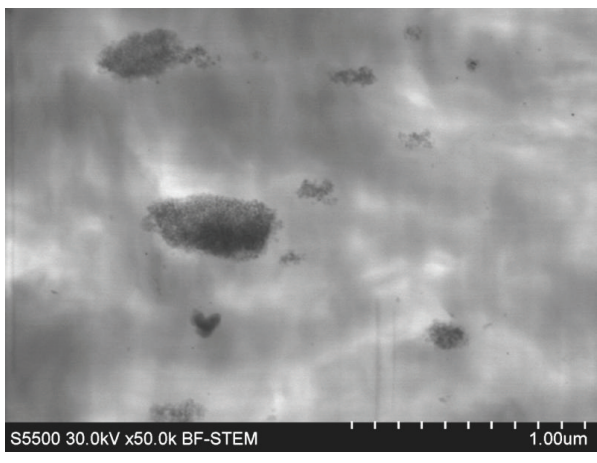

(a)

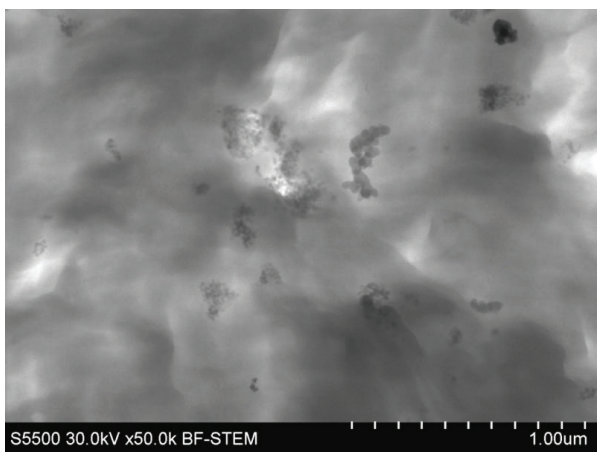

(c)

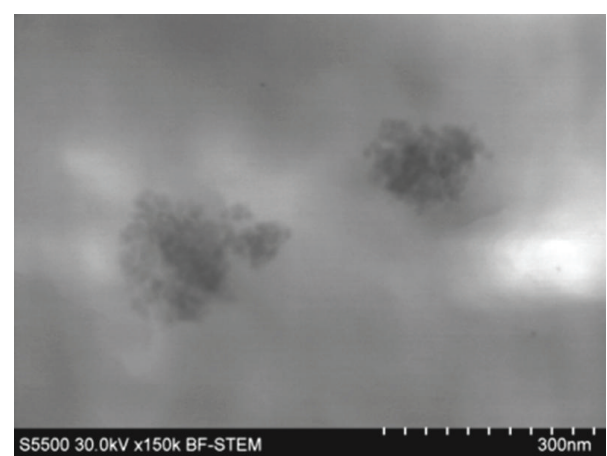

(b)

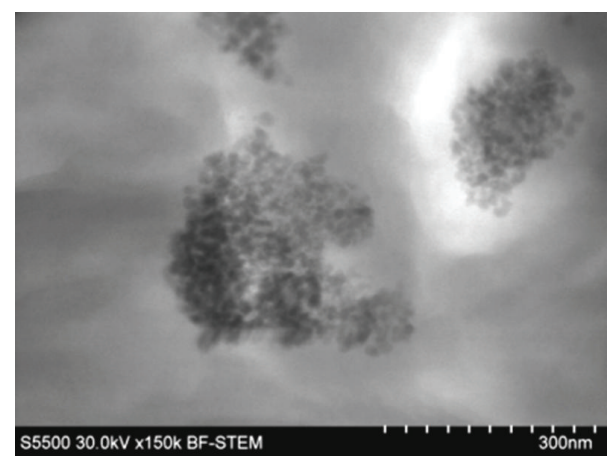

(d)

Figure 4: TEM images of HDPE/Ag-SiO 2 composites: 10 wt.\% $\mathrm{Ag}_{-} \mathrm{SiO}_{2}$ ((a), (b)), 15 wt.\% $\mathrm{Ag}-\mathrm{SiO}_{2}$ ((c), (d)).

that the neat silica nanoparticles tend to form agglomerates because of the formation of hydrogen bonds among the abundant hydroxyl groups and adsorbed water on their surface. This effect is more pronounced for higher concentrations of nanosilica $[24,25]$. After modification by silver or copper, majority of hydroxyl groups have reacted and silver or copper nanoparticles covered the silica surface. This produces a better dispersion of the silica particles in the polymer matrix, and as a consequence the composite properties improved [17]. Therefore, silica containing immobilized nanosilver or nanocopper presents lower tendency to form agglomerates than neat silica so it can be used at higher concentrations ( $\geq 10 \mathrm{wt} . \%)$ to give bactericidal properties to the polymer modified. However, the surface activity of the silica is extremely high and the particles consequently have a tendency to aggregate tightly creating micron-sized silicacluster [23].

Transmission electron microscopy was performed to explain the behavior of the silica-filled HDPE composites. Figures 4 and 5 show the dispersion state of silica-filled HDPE composites. Comparing composites containing different concentrations of silica, the dispersion of individual silica nanoparticles in the HDPE matrix is finer at lower silica content (10 wt.\%). However, the two concentrations of silica are relatively high for such fillers. From the TEM images it is clear that $\mathrm{Cu}-\mathrm{SiO}_{2}$ shows bigger tendency to form agglomerates than $\mathrm{Ag}-\mathrm{SiO}_{2}$. One possible explanation of this fact could be that the hydrodynamic force induced in the polymer melt during melt compounding exceeds the cohesive force acting between the silica particles forming the agglomerates, resulting in the dispersion of the isolated large silica particles in the HDPE matrix. Moreover, the shear stress induced in the kneaded HDPE melt is not sufficient to provide nanometric dispersion of silica nanoparticles. However, isolated silica nanoparticles were observed inside agglomerates (see Figures 4 and 5).

3.2. Crystallization Behavior of the Silica-Filled HDPE Composites. The effect of nanosilica containing immobilized silver or copper nanoparticles on crystallization behavior of HDPE was determined by DSC measurements. Figures 6 and 7 show the second heating and cooling DSC curves of HDPE and investigated silica-filled HDPE composites. The important data obtained are listed in Table 3. It is clear from the results that the addition of silica nanoparticles shows no effect on the melting temperature $\left(T_{m}\right)$ of HDPE matrix. Moreover, there is no effect on the crystallinity of the matrix although the crystallization process starts at a higher temperature. The crystallinity values of HDPE matrix in silica-filled composites are decreased to a maximum $3 \%$ achieved by $\mathrm{HDPE} / \mathrm{Ag}-\mathrm{SiO}_{2}$ composite containing $15 \%$ of $\mathrm{Ag}-\mathrm{SiO}_{2}$. The crystallization temperatures $\left(T_{c}\right)$ of HDPE in the composites are slightly increased as a function of silica content with a maximum improvement of $3^{\circ} \mathrm{C}$. Based on these results, it can be concluded that the crystalline features of HDPE have not been influenced greatly by addition of both silver and copper modified silica nanoparticles. Probably, 


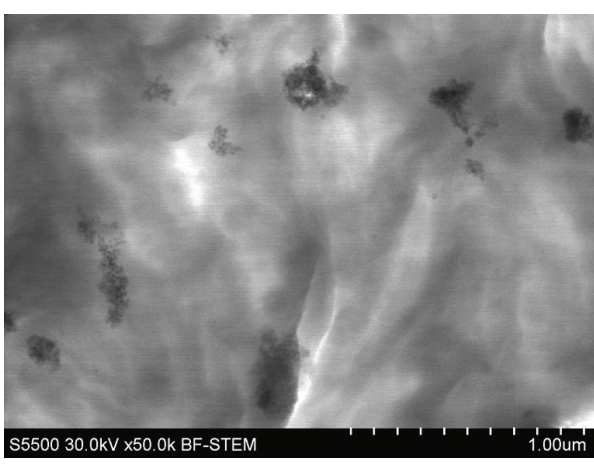

(a)

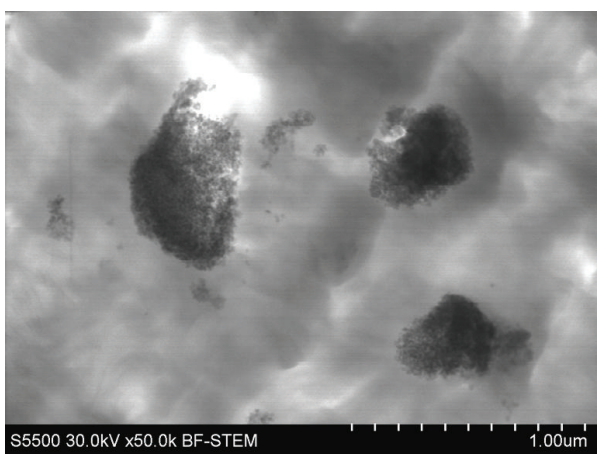

(c)

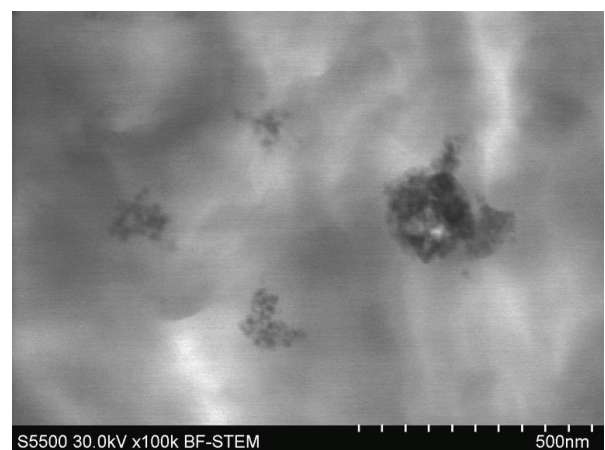

(b)

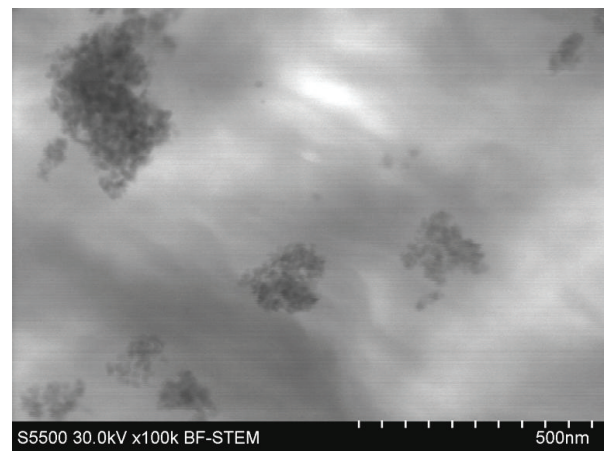

(d)

Figure 5: TEM images of $\mathrm{HDPE} / \mathrm{Cu}-\mathrm{SiO}_{2}$ composites: 10 wt.\% $\mathrm{Cu}-\mathrm{SiO}_{2}$ ((a), (b)), 15 wt.\% $\mathrm{Ag}-\mathrm{SiO}_{2}$ ((c), (d)).

the presence of nanoparticles prevents the growth of HDPE crystals due to small interparticle distances [26].

3.3. Thermogravimetric Analysis. The TGA curves of the neat HDPE and silica-filled composites in an air atmosphere are displayed in Figure 8 . The onset $\left(T_{\text {on }}\right)$, maximum $\left(T_{\max }\right)$, and thermooxidative decomposition temperatures at 10\% $\left(T_{10}\right)$ and $50 \%$ weight loss $\left(T_{50}\right)$ are evaluated from the TGA curves, as listed in Table 4. It was found that the presence of silica significantly altered the degradation mechanism of HDPE. $T_{\text {on }}, T_{10}, T_{50}$, and $T_{\max }$ of neat HDPE are about $359,374,424$, and $440^{\circ} \mathrm{C}$, respectively. It was observed that silica containing immobilized silver or copper significantly improved thermal properties of HDPE composites due to the $13-41^{\circ} \mathrm{C}$ higher thermooxidative decomposition temperatures. The onset, maximum, and thermooxidative decomposition temperatures at $50 \%$ weight loss of the $\mathrm{HDPE} / \mathrm{Ag}-\mathrm{SiO}_{2}$ composites are higher than of neat HDPE and tend to increase at higher silica content. Although $T_{10}$ of the composite filled with silica containing immobilized nanosilver is higher in comparison with neat HDPE, it unfortunately slightly decreases with increasing silica content.

In the case of $\mathrm{HDPE} / \mathrm{Cu}-\mathrm{SiO}_{2}$ composites $T_{50}$ and $T_{\max }$ values are higher compared to neat HDPE but decrease with increasing silica content. The decrease in thermooxidative stability at higher silica content could be attributed to nanoparticles agglomeration [24, 27]. This is in a good agreement with TEM micrographs discussed above (see Figures 4 and 5).
TABLE 3: DSC test: thermal transition properties (second run) of HDPE-based composites filled with different contents of $\mathrm{Ag}-\mathrm{SiO}_{2}$ or $\mathrm{Cu}-\mathrm{SiO}_{2}$.

\begin{tabular}{lccc}
\hline Sample & $T_{m}\left({ }^{\circ} \mathrm{C}\right)$ & $T_{c}\left({ }^{\circ} \mathrm{C}\right)$ & $X_{c}{ }^{a}(\%)$ \\
\hline $\mathrm{HDPE}$ & 134 & 118 & 68 \\
$\mathrm{HDPE} / \mathrm{Ag}-\mathrm{SiO}_{2}(90 / 10)$ & 133 & 120 & 66 \\
$\mathrm{HDPE} / \mathrm{Ag}-\mathrm{SiO}_{2}(85 / 15)$ & 133 & 121 & 65 \\
$\mathrm{HDPE} / \mathrm{Cu}-\mathrm{SiO}_{2}(90 / 10)$ & 133 & 120 & 68 \\
$\mathrm{HDPE} / \mathrm{Cu}-\mathrm{SiO}_{2}(85 / 15)$ & 133 & 121 & 67 \\
\hline
\end{tabular}

${ }^{a}$ Assessed by integrating the normalized area of the melting endothermic peak and rationing the heat involved to the reference value of $100 \%$ crystalline HDPE $(293 \mathrm{~J} / \mathrm{g})$.

An increase in the thermal stability of silica-filled HDPE composites may be explained by the formation of the HDPEsilica nanoparticles network by the physical crosslinking of HDPE via silica nanoparticles; this causes the whole system to be stabilized due to the thermal motions of the HDPE chains being restricted.

3.4. Dynamic Mechanical Properties. In order to evaluate the effect of $\mathrm{Ag}-\mathrm{SiO}_{2}$ as well as $\mathrm{Cu}-\mathrm{SiO}_{2}$ nanoparticles on the HDPE matrix, thermomechanical properties were measured. Due to the very high surface area of the nanoparticles in the HDPE composites, the applied stress is expected to be easily transferred from the matrix onto the silica particles resulting in an enhancement of the mechanical properties. 


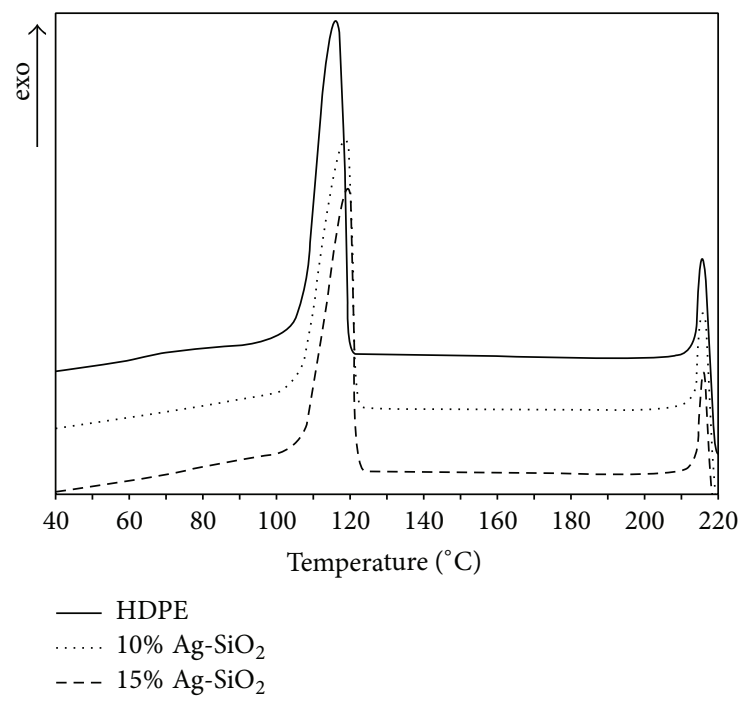

(a)

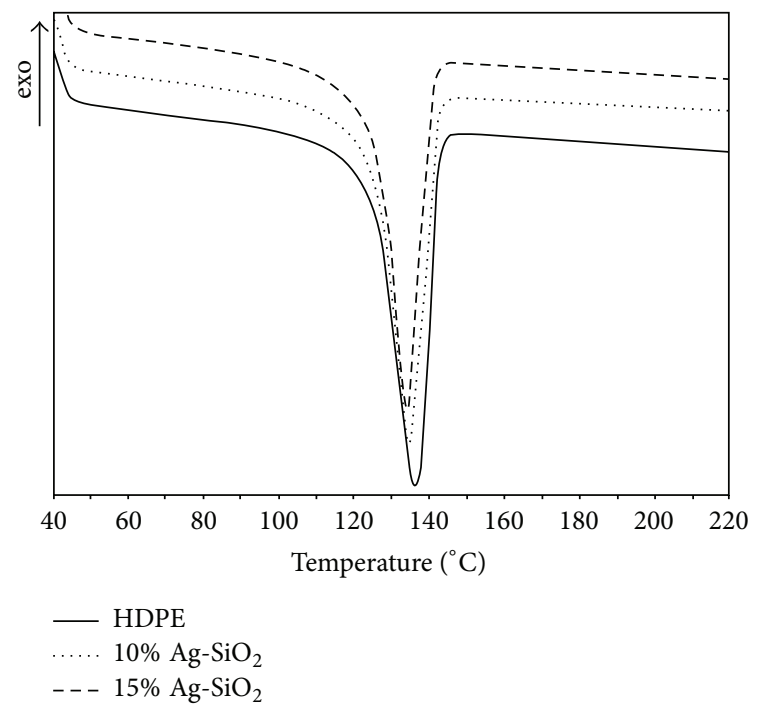

(b)

FIGURE 6: DSC curves of HDPE and nanosilica containing immobilized nanosilver filled HDPE composites: second heating (a) and cooling run (b).

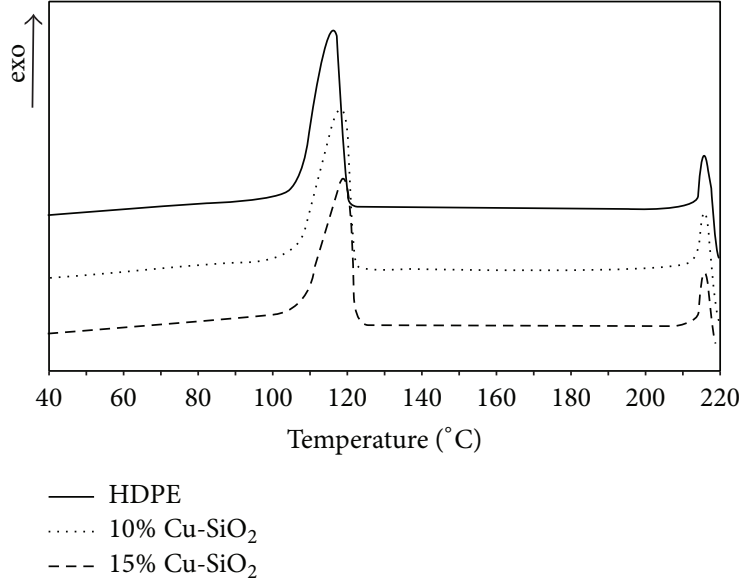

(a)

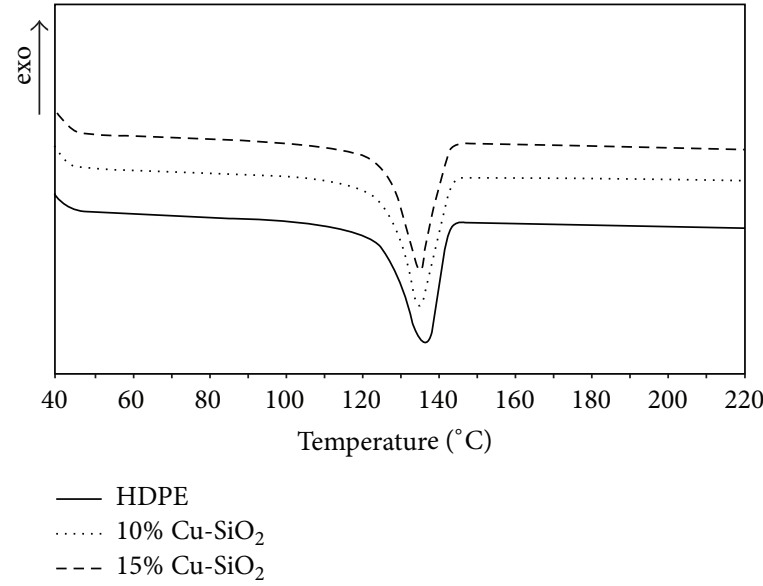

(b)

FIGURE 7: DSC curves of HDPE and nanosilica containing immobilized nanocopper filled HDPE composites: second heating (a) and cooling run (b).

Figures 9 and 10 compare the variation of storage modulus $\left(G^{\prime}\right)$, loss modulus $\left(G^{\prime \prime}\right)$, and loss tangent $(\tan \delta)$ as a function of temperature, measured at frequency $1 \mathrm{~Hz}$, for HDPE and the silica-filled HDPE composites studied. These samples present two well-expressed relaxations, $\alpha$ and $\gamma$, and a very weak $\beta$ relaxation. Table 5 summarizes the results for storage modulus at room temperature and temperatures of $\alpha, \beta$, and $\gamma$ relaxations.

The storage modulus of the HDPE/Ag-SiO 2 and HDPE/ $\mathrm{Cu}-\mathrm{SiO}_{2}$ composites was significantly higher than corresponding HDPE in the $\beta$ and $\alpha$ relaxations regions, due to the stiffening effect of the silica. As showed in Table 5, the addition of $\mathrm{Ag}-\mathrm{SiO}_{2}$ to HDPE improved $\mathrm{G}^{\prime}$ at $23^{\circ} \mathrm{C}$ by about $10-15 \%$. Silica could hinder the chain motion of HDPE, which would improve the modulus. As a result of these changes, the storage modulus of the interface is higher than that of the free part. An increase in the $\mathrm{Ag}-\mathrm{SiO}_{2}$ content enlarges the interfacial area and results in increased volume of interphase.

The $\alpha$ relaxation is well expressed as a maximum in loss modulus and as a small hump before the melting process in the temperature dependence of $\tan \delta$. This relaxation appears centered at $42^{\circ} \mathrm{C}$ for HDPE. The addition of silica containing immobilized nanosilver or nanocopper increases $\alpha$ relaxation to about $46^{\circ} \mathrm{C}$. However, the value of the $\alpha$ relaxation strongly depends on the type and content of silica. Moreover, it can be seen that the composites show higher $\alpha$ peak intensity compared to neat HDPE indicating higher 
TABLE 4: TGA test: thermooxidative decomposition temperatures of HDPE-based composites filled by different weight percentages of Ag$\mathrm{SiO}_{2}$ or $\mathrm{Cu}-\mathrm{SiO}_{2}$.

\begin{tabular}{lccccc}
\hline Sample & $T_{\text {on }}\left({ }^{\circ} \mathrm{C}\right)$ & $T_{10}\left({ }^{\circ} \mathrm{C}\right)$ & $T_{50}\left({ }^{\circ} \mathrm{C}\right)$ & $T_{\max }\left({ }^{\circ} \mathrm{C}\right)$ & Residue weight $(\%)$ \\
\hline $\mathrm{HDPE}$ & 359 & 374 & 424 & 440 & 0 \\
$\mathrm{HDPE} / \mathrm{Ag}-\mathrm{SiO}_{2}(90 / 10)$ & 400 & 396 & 455 & 462 & 8.6 \\
$\mathrm{HDPE} / \mathrm{Ag}-\mathrm{SiO}_{2}(85 / 15)$ & 404 & 390 & 463 & 464 & 13.1 \\
$\mathrm{HDPE} / \mathrm{Cu}-\mathrm{SiO}_{2}(90 / 10)$ & 400 & 393 & 457 & 467 & 7.5 \\
$\mathrm{HDPE} / \mathrm{Cu}-\mathrm{SiO}_{2}(85 / 15)$ & 400 & 400 & 437 & 458 & 11.4 \\
\hline
\end{tabular}

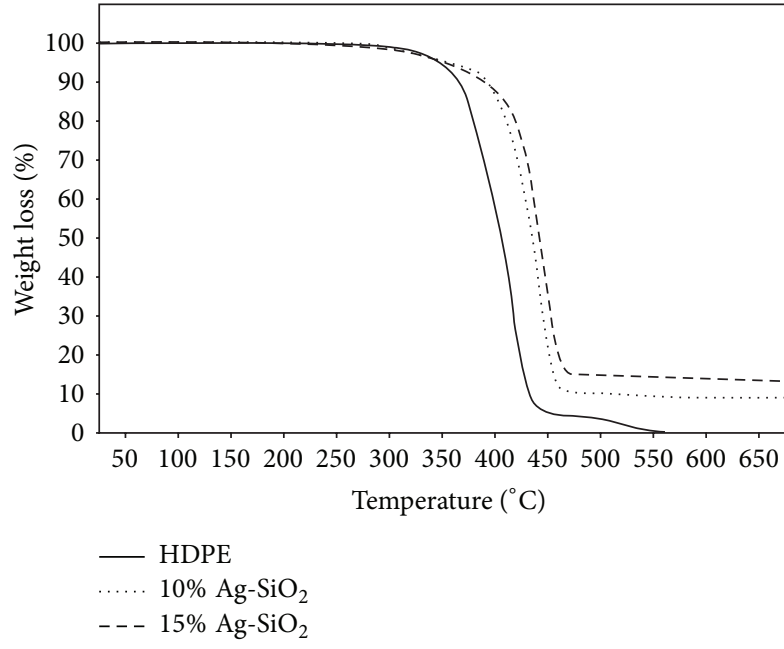

(a)

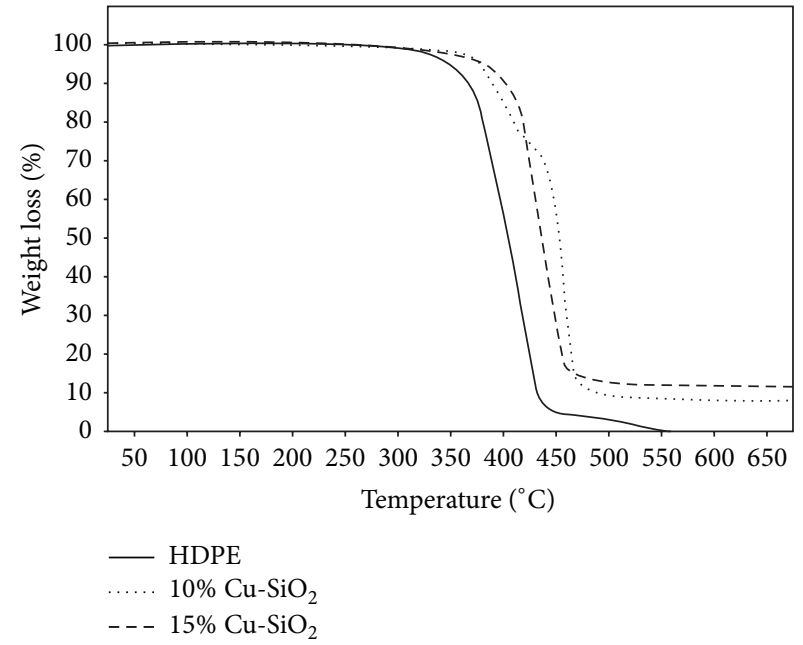

(b)

FIGURE 8: TGA curves of HDPE and HDPE composites with nanosilica containing immobilized nanosilver (a) and nanocopper (b).

stiffness of the material. The $\alpha$ relaxation has been defined as the reorientation of molecules within the crystal [28]. It was reported [29] that there is a relation between crystallites' thickness and intensity of the $\alpha$ relaxation and that this process is affected by the chain mobility of the crystallites. Therefore, chain mobility occurs at higher temperature as crystallite thickness increases. The position and intensity of the $\alpha$ relaxation maximum is usually connected with crystallites' thickness and crystallinity level, respectively [30].

The $\gamma$ relaxation occurs as a maximum at $-118^{\circ} \mathrm{C}$ for the $\mathrm{HDPE}$, from $-118^{\circ} \mathrm{C}$ to $-122^{\circ} \mathrm{C}$ for the composites in loss modulus, and at slightly higher temperatures in $\tan \delta$, with corresponding decrease in storage modulus, compare Table 5 and Table 6 . This is a clear effect of silica containing immobilized nanosilver or nanocopper loading on the breadth and location of the relaxation; this process is shifted to lower temperatures in the presence of silica, as a consequence of slightly lower crystallinity as compared to HDPE. The $\gamma$ relaxation has been associated with a single relaxation process, predominantly of amorphous origin. This relaxation is typical for the joint movements of chains containing three or more methylene groups (units) in the main chain $[29,30]$. The intensity of the $\gamma$ relaxation is usually associated with the amorphous region of semicrystalline polymers. Therefore, the decrease in the intensity of $\gamma$ relaxation of the silica-filled composites can be attributed to the decrease in the quantity of the amorphous phase. It was reported that the position of $\gamma$ loss modulus peak can change between $-125^{\circ} \mathrm{C}$ and $-105^{\circ} \mathrm{C}$ depending on the type of polyethylene (LDPE, LLDPE, or HDPE) and therefore on crystallinity degree (between $20 \%$ and 70\%) [31-33].

At temperatures below the $\gamma$ relaxation storage modulus $G^{\prime}$ of the HDPE/Ag-SiO${ }_{2}$ composites becomes smaller than of $\mathrm{HDPE}$ as well as the $\mathrm{HDPE} / \mathrm{Cu}-\mathrm{SiO}_{2}$ composites. One possible explanation of this fact could be that below that relaxation the modulus of elasticity of the amorphous phase is higher than that of the crystal one. These samples have the lowest quantity of amorphous phase (see Figures 9(b) and 10(b)) and moreover the physical cross-linking now could not contribute to the increasing of the storage modulus.

The $\beta$ relaxation can be observed as a weak maximum in loss modulus (Figures 9(b) and 10(b)) for HDPE and silica-filled HDPE composites. It was found that $\beta$ relaxation occurs between $-5^{\circ} \mathrm{C}$ and $-50^{\circ} \mathrm{C}$ depending upon the type of polyethylene $[30,33,34]$. Some authors have concluded that the $\beta$ relaxation results from motion of chain units in the interfacial region [34], whereas others attributed this process to the glass transition [31]. Nitta and Tanaka have suggested a different molecular origin of the $\beta$ relaxation in linear polyethylene with high molecular weights quite dissimilar to those aforementioned for branched polyethylene [30]. Because of the formation of loose tie and loop molecules in 


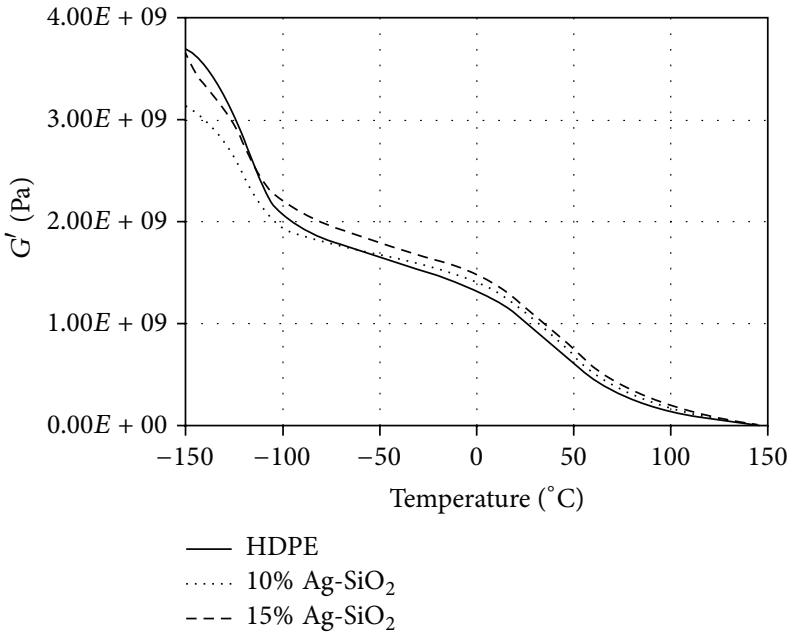

(a)

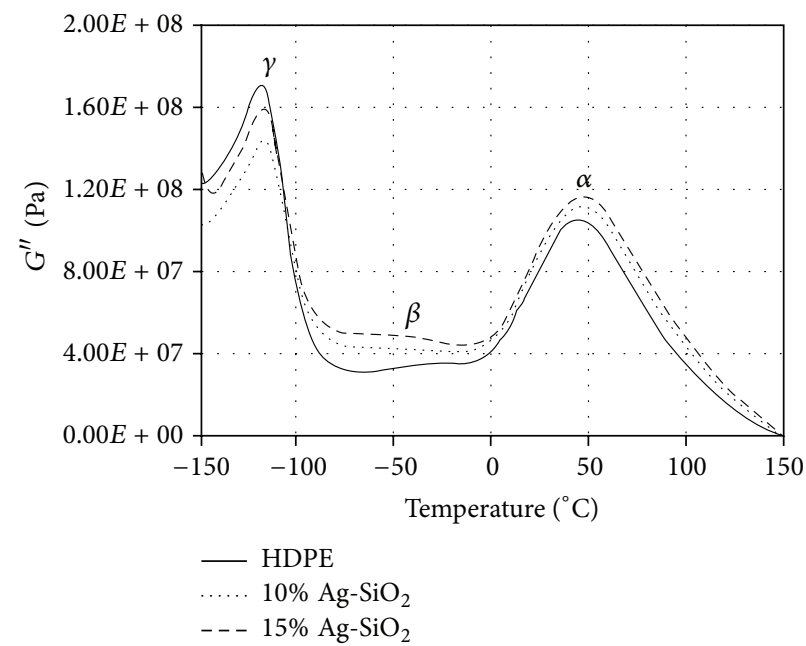

(b)

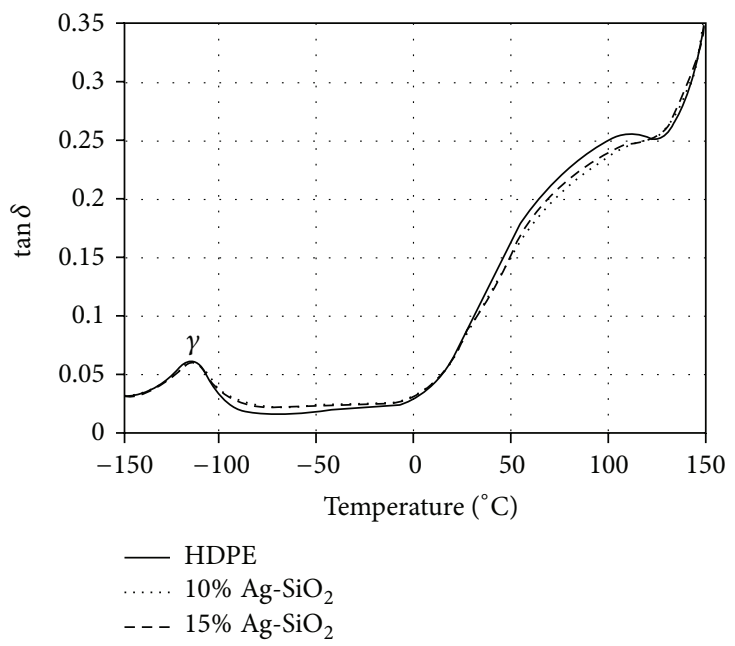

(c)

FIGURE 9: Dynamic mechanical relaxation behavior versus temperature of HDPE and silica containing immobilized nanosilver filled HDPE composites at frequency of $1 \mathrm{~Hz}: G^{\prime}(\mathrm{a}), G^{\prime \prime}(\mathrm{b})$, and $\tan \delta(\mathrm{c})$.

TABLE 5: DMTA results for HDPE and the HDPE composites containing Ag-SiO${ }_{2}$ or $\mathrm{Cu}-\mathrm{SiO}_{2}$.

\begin{tabular}{|c|c|c|c|c|c|c|c|}
\hline \multirow{2}{*}{ Sample } & \multirow{2}{*}{ Storage modulus $(\mathrm{MPa})$ at $23^{\circ} \mathrm{C}$} & \multicolumn{3}{|c|}{ Loss modulus (peak position) $\left({ }^{\circ} \mathrm{C}\right)$} & \multicolumn{3}{|c|}{ Loss modulus (peak high) (MPa) } \\
\hline & & $T_{\gamma}$ & $T_{\beta}$ & $T_{\alpha}$ & $T_{\gamma}$ & $T_{\beta}$ & $T_{\alpha}$ \\
\hline HDPE & 1140 & -120.2 & -36.3 & 41.9 & 169 & 35.7 & 105 \\
\hline $\mathrm{HDPE} / \mathrm{Ag}-\mathrm{SiO}_{2}(90 / 10)$ & 1250 & -119.6 & -47.1 & 44.1 & 143 & 43.6 & 112 \\
\hline $\mathrm{HDPE} / \mathrm{Ag}-\mathrm{SiO}_{2}(85 / 15)$ & 1320 & -119.9 & -51.3 & 44.6 & 157 & 49.7 & 116 \\
\hline $\mathrm{HDPE} / \mathrm{Cu}-\mathrm{SiO}_{2}(90 / 10)$ & 1240 & -122.0 & -41.8 & 45.7 & 157 & 36.3 & 113 \\
\hline $\mathrm{HDPE} / \mathrm{Cu}-\mathrm{SiO}_{2}(85 / 15)$ & 1270 & -121.8 & -47.1 & 44.5 & 163 & 40.5 & 116 \\
\hline
\end{tabular}

the amorphous layers in polyethylene with high molecular weights, the $\beta$ relaxation seems to be a consequence of the motion of the loose tie molecules in this type of polyethylene. The absence of the $\beta$ relaxation in typical linear polyethylene having a thinner amorphous layer, which is considered to promote taut tie molecules, can be directly attributed to the lack of loose tie molecules [35].
The $\beta$-relaxation appears as a maximum at $-36^{\circ} \mathrm{C}$ for HDPE and $5-15^{\circ} \mathrm{C}$ lower temperature for the HDPE composites. Evidently, the $\mathrm{HDPE} / \mathrm{Ag}-\mathrm{SiO}_{2}$ composite containing 15 wt. $\% \mathrm{Ag}_{-} \mathrm{SiO}_{2}$ shows the highest intensity of $\beta$ transition peak amongst all the samples. This is related to increased interfacial interactions between $\mathrm{HDPE}$ matrix and $\mathrm{Ag}-\mathrm{SiO}_{2}$ or $\mathrm{Cu}-\mathrm{SiO}_{2}$ nanoparticles. 


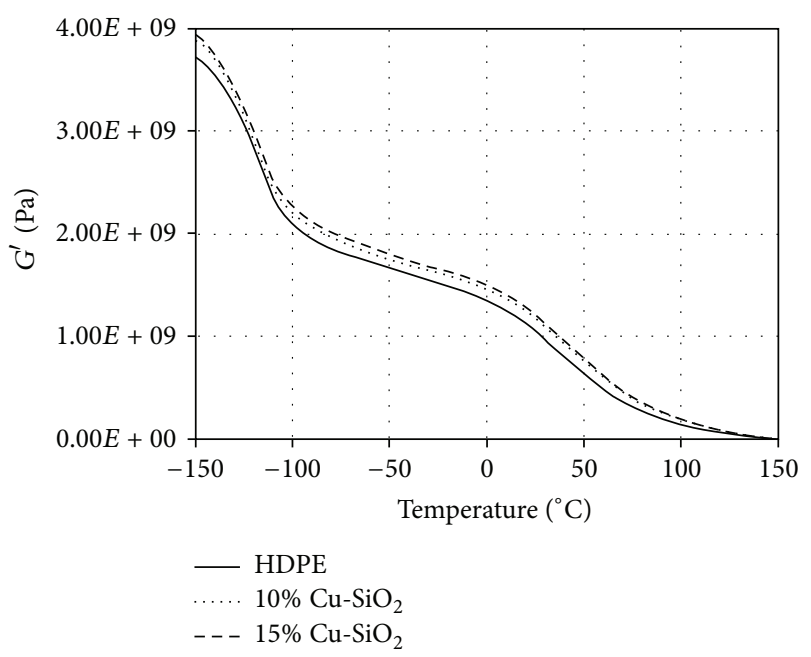

(a)

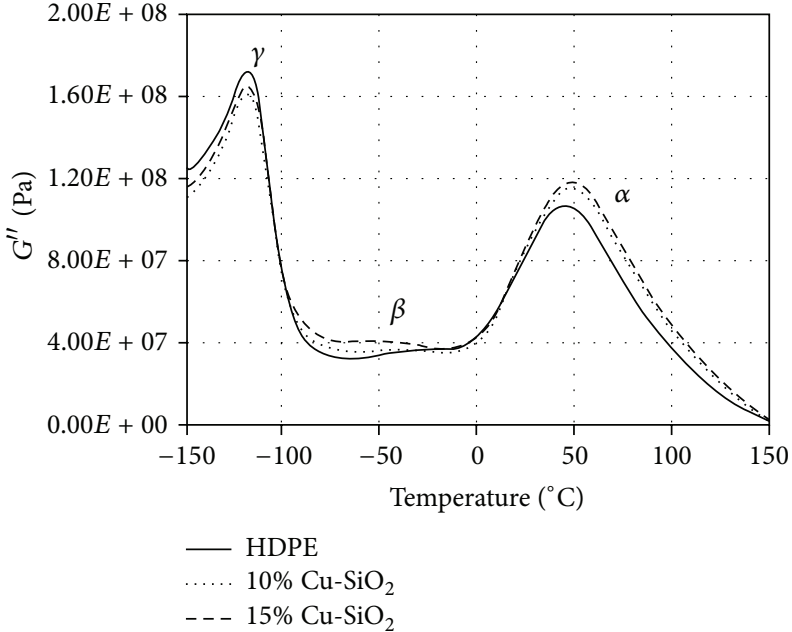

(b)

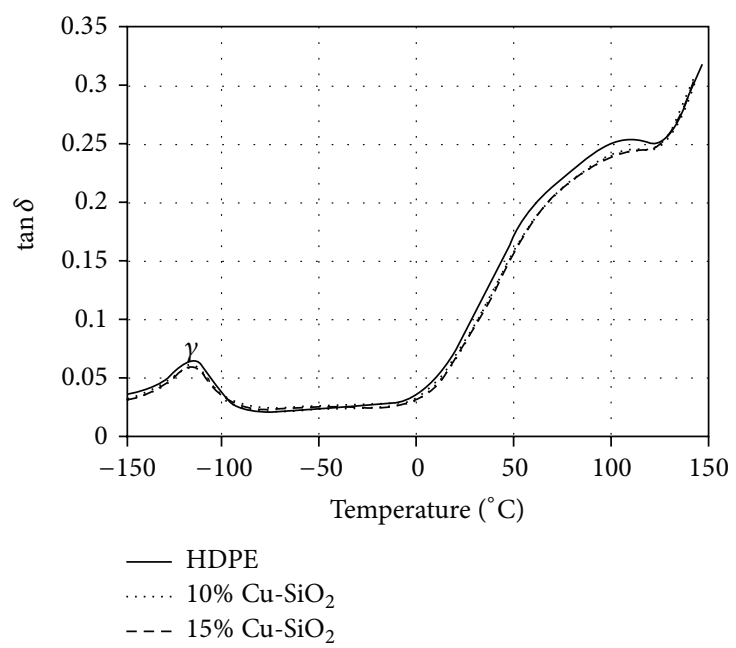

(c)

FIGURE 10: Dynamic mechanical relaxation behavior versus temperature of HDPE and silica containing immobilized nanocopper filled HDPE composites at frequency of $1 \mathrm{~Hz}: G^{\prime}(\mathrm{a}), G^{\prime \prime}(\mathrm{b})$, and $\tan \delta(\mathrm{c})$.

3.5. Mechanical Properties. The mechanical properties of polymer composites depend crucially upon the efficiency of stress transfer from the polymer matrix to the fillers, which will be influenced by the interphase. The interphase in composites is the boundary layer between filler surface and polymer matrix, which exhibits local properties different from those of the bulk matrix.

The effect of silica containing immobilized nanosilver or nanocopper on the mechanical properties of HDPE composites is summarized in Table 7. The incorporation of both types of silica nanoparticles reinforces HDPE but reduces the ductility of the matrix. Moreover, the addition of silica containing immobilized nanosilver as well as nanocopper significantly increases the material stiffness indicated by overall increased tensile and flexural moduli. Besides, this effect increases with increasing silica content. However, the greater improvement in flexural than in tensile modulus was observed. The maximum improvement in flexural modulus is almost $50 \%$ achieved for both types of silica. Since the crystallinity of matrix in the HDPE/Ag-SiO 2 and $\mathrm{HDPE} / \mathrm{Cu}-$ $\mathrm{SiO}_{2}$ composites is lower compared to neat HDPE, the increase in tensile and flexural moduli should be attributed to the rigid particles themselves. It is well known that the improvement in the modulus depends on the morphology of nanocomposites $[24,27,36]$. Reinforcing efficiency of the nanofiller is balanced by two opposite phenomena. The negative effect can be attributed to migration of nanoparticles into the interphase of particle-matrix causing worse performance. Dispersion of nanosilica as positive effect could enhance the modulus.

As can be seen silica improved tensile and flexural strength of HDPE matrix. However, the greater improvement $(35 \%)$ in flexural than tensile strength was observed. Generally, the tensile and flexural strength mainly depends on the 
TABLE 6: DMTA results for HDPE and the HDPE composites containing Ag-SiO 2 or $\mathrm{Cu}-\mathrm{SiO}_{2}$.

\begin{tabular}{lcc}
\hline Sample & Loss tangent $($ peak position $)\left({ }^{\circ} \mathrm{C}\right)$ & \multicolumn{2}{c}{ Loss tangent (peak high) } \\
& $T_{\gamma}$ & 0.0630 \\
$\mathrm{HDPE}$ & -116.4 & 0.0605 \\
$\mathrm{HDPE} / \mathrm{Ag}-\mathrm{SiO}_{2}(90 / 10)$ & -116.8 & 0.0584 \\
$\mathrm{HDPE} / \mathrm{Ag}-\mathrm{SiO}_{2}(85 / 15)$ & -117.6 & 0.0567 \\
$\mathrm{HDPE} / \mathrm{Cu}-\mathrm{SiO}_{2}(90 / 10)$ & -117.5 & 0.0567 \\
$\mathrm{HDPE} / \mathrm{Cu}-\mathrm{SiO}_{2}(85 / 15)$ & -117.6 & \\
\hline
\end{tabular}

TABLE 7: Tensile, flexural and impact properties of HDPE and the HDPE composites containing Ag-SiO ${ }_{2}$ or $\mathrm{Cu}-\mathrm{SiO}_{2}$; tensile and flexural testing speed $5 \mathrm{~mm} / \mathrm{min}$.

\begin{tabular}{|c|c|c|c|c|c|}
\hline \multirow{2}{*}{ Property } & \multirow{2}{*}{ HDPE } & \multicolumn{2}{|c|}{$\mathrm{Ag}-\mathrm{SiO}_{2}$ (wt.\%) } & \multicolumn{2}{|c|}{$\mathrm{Cu}-\mathrm{SiO}_{2}$ (wt.\%) } \\
\hline & & 10 & 15 & 10 & 15 \\
\hline Tensile strength (MPa) & $23 \pm 0.2$ & $26 \pm 0.1$ & $27 \pm 0.3$ & $26 \pm 0.3$ & $27 \pm 0.3$ \\
\hline Elongation at break (\%) & $438 \pm 20$ & $149 \pm 12$ & $42 \pm 11$ & $145 \pm 18$ & $32 \pm 3$ \\
\hline Tensile modulus (MPa) & $1390 \pm 12$ & $1520 \pm 10$ & $1600 \pm 14$ & $1570 \pm 16$ & $1690 \pm 18$ \\
\hline Flexural strength $(\mathrm{MPa})$ & $18 \pm 0.2$ & $24 \pm 0.3$ & $25 \pm 0.2$ & $23 \pm 0.4$ & $25 \pm 0.5$ \\
\hline Flexural modulus (MPa) & $640 \pm 10$ & $898 \pm 14$ & $950 \pm 12$ & $893 \pm 28$ & $949 \pm 15$ \\
\hline Charpy impact strength $\left(\mathrm{kJ} / \mathrm{m}^{2}\right)$ & $4.0 \pm 0.2$ & $4.0 \pm 0.6$ & $4.1 \pm 0.3$ & $3.6 \pm 0.3$ & $3.2 \pm 0.4$ \\
\hline
\end{tabular}

TABLE 8: Vitality of E. coli and St. aureus onto HDPE and the $\mathrm{HDPE} / \mathrm{Ag}-\mathrm{SiO}_{2}$ and $\mathrm{HDPE} / \mathrm{Cu}-\mathrm{SiO}_{2}$ composites surface determined using ATP method.

\begin{tabular}{lcc}
\hline \multirow{2}{*}{ Sample } & \multicolumn{2}{c}{ ATP $\left(\mathrm{RLU} / \mathrm{cm}^{2}\right)$} \\
& E. coli & St. aureus \\
\hline $\mathrm{HDPE}$ & 2800 & 603 \\
$\mathrm{HDPE} / \mathrm{Ag}-\mathrm{SiO}_{2}(90 / 10)$ & 1007 & 170 \\
$\mathrm{HDPE} / \mathrm{Ag}-\mathrm{SiO}_{2}(85 / 15)$ & 2133 & 1273 \\
$\mathrm{HDPE} / \mathrm{Cu}-\mathrm{SiO}_{2}(90 / 10)$ & 1050 & 240 \\
$\mathrm{HDPE} / \mathrm{Cu}-\mathrm{SiO}_{2}(85 / 15)$ & 2600 & 1800 \\
\hline
\end{tabular}

TABle 9: Vitality of Salmonella typhimurium, Pseudomonas fluorescens and Burkholderia cepacia onto HDPE and the HDPE/Ag$\mathrm{SiO}_{2}(90 / 10)$ and $\mathrm{HDPE} / \mathrm{Cu}-\mathrm{SiO}_{2}(90 / 10)$ composites surface determined using ATP method.

\begin{tabular}{lccc}
\hline Sample & \multicolumn{3}{c}{$\mathrm{ATP}\left(\mathrm{RLU} / \mathrm{cm}^{2}\right)$} \\
$\begin{array}{c}\text { Salmonella } \\
\text { typhimurium }\end{array}$ & $\begin{array}{c}\text { Pseudomonas } \\
\text { fluorescens }\end{array}$ & $\begin{array}{c}\text { Burkholderia } \\
\text { cepacia }\end{array}$ \\
\hline $\begin{array}{l}\mathrm{HDPE} \\
\mathrm{HDPE} / \mathrm{Ag}-\mathrm{SiO}_{2}\end{array}$ & 5675 & 2037 & 2150 \\
$\begin{array}{l}(90 / 10) \\
\mathrm{HDPE} / \mathrm{Cu}-\mathrm{SiO}_{2}\end{array}$ & 1606 & 740 & 1400 \\
$(90 / 10)$ & 683 & 880 & 1125 \\
\hline
\end{tabular}

interfacial interactions between polymer matrix and a filler. This could suggest very good interfacial adhesion between HDPE matrix and silica containing immobilized nanosilver or nanocopper.

Correlating the crystalline behavior and mechanical properties of $\mathrm{Ag}-\mathrm{SiO}_{2}$ or $\mathrm{Cu}-\mathrm{SiO}_{2} \mathrm{HDPE}$ composites, one can conclude that the improvements in tensile and flexural properties of composites are mainly caused by the change of the stress state around the nanoparticles, because decreased crystallinity and spherulite size can only lead to decreased stiffness and strength [37]. Of course, the effect of crystalline behavior of matrix on the fracture toughness of a crystalline polymer is very complicated and needs to be further investigated.

Moreover, impact strength of the composites strongly depends on the type as well as concentration of silica nanoparticles. However, the addition of silica containing immobilized nanosilver shows no effect on the impact strength. Unlike, the composites filled with $\mathrm{Cu}-\mathrm{SiO}_{2}$ exhibit lower impact strength compared to the neat HDPE. Additionally, impact strength decreases as a function of $\mathrm{Cu}-$ $\mathrm{SiO}_{2}$ content, due to the growing degree of nanoparticles agglomeration. These results are in good agreement with TEM studies.

3.6. Bactericidal Activity. Bactericidal properties of HDPE composites containing the silica with immobilized nanosilver or nanocopper were examined against E. coli, St. aureus, Salmonella typhimurium, Pseudomonas fluorescens, and Bulkolderia cepacia following the ATP test method and the results are shown in Tables 8 and 9. The active nanosilver and nanocopper present in the HDPE composites containing $10 \mathrm{wt} . \%$ of nanosilica have a significant influence on the material bactericidal activity. Unlikely, the huge growth of ATP content for St. aureus onto the composites surface for higher silica content (15 wt.\%) was observed. It could be due to the agglomeration of silica nanoparticles. Therefore, this negative effect was much more pronounced for $\mathrm{Cu}-\mathrm{SiO}_{2}$ than 
$\mathrm{Ag}-\mathrm{SiO}_{2}$ nanoparticles. Two processes may be considered to explain this finding.

(i) The bacteria were killed by silver or copper nanoparticles immobilized on the silica surface (bactericidal effect).

(ii) The bacteria survived but could not grow to colonies on the polymer surface. The silver or cooper nanoparticles immobilized on the silica surface inhibited the growth of bacterial cells (bacteriostatic effect).

From the results shown in Tables 8 and 9 it can be concluded that 10 wt. $\%$ of $\mathrm{Ag}-\mathrm{SiO}_{2}$ or $\mathrm{Cu}-\mathrm{SiO}_{2}$ would be sufficient for the HDPE composites to provide good activity against different kinds of bacteria (E. coli, St. aureus, Salmonella typhimurium, Pseudomonas fluorescens, and Burkholderia cepacia), due to the significant ATP reduction (between 50 and $90 \%$ ). The highest efficacy of the composites containing $10 \mathrm{wt}$ \% of $\mathrm{Cu}-\mathrm{SiO}_{2}$ against Salmonella was observed. Correlating the mechanical and bactericidal properties of the Ag$\mathrm{SiO}_{2}$ or $\mathrm{Cu}-\mathrm{SiO}_{2} \mathrm{HDPE}$ composites, one can conclude that the agglomeration of nanoparticles within polymer matrix has stronger effect for bactericidal activity than mechanical properties. It can be explained by very good interfacial adhesion between nanoparticles surface and polymer matrix.

\section{Conclusions}

In this study, the silica nanoparticles containing immobilized nanosilver or nanocopper were compounded in HDPE by melt blending. From the TEM images it is clear that $\mathrm{Cu}-\mathrm{SiO}_{2}$ shows bigger tendency to form agglomerates than $\mathrm{Ag}-\mathrm{SiO}_{2}$. However, individual silica nanoparticles separated by the polymer matrix could be seen inside agglomerates. Based on DSC results, it can be concluded that the crystalline features of HDPE have not been influenced greatly by addition of both silver and copper modified silica nanoparticles. Probably, the presence of nanoparticles prevents the growth of HDPE crystals due to small interparticle distances. The thermal stability of the composites containing $\mathrm{Ag}-\mathrm{SiO}_{2}$ as well as $\mathrm{Cu}-\mathrm{SiO}_{2}$ nanoparticles was extremely better compared to neat HDPE. From DMTA measurements, both storage modulus and loss modulus of all HDPE/silica composites are increased in $\beta$ and $\alpha$ relaxation regions indicating that the material became stiffer. Moreover, the gradual enhancement in tensile and flexural strength of the HDPE composites was observed. The addition of silica nanoparticles to the HDPE increased tensile modulus and flexural modulus, pointing to a synergetic effect arising from the presence of the reinforced HDPE phase and very good interfacial interactions between nanoparticles surface and polymer matrix. Maximum improvement in flexural modulus is about $50 \%$ achieved by the HDPE composite containing 15 wt.\% of $\mathrm{Ag}-\mathrm{SiO}_{2}$ as well as $\mathrm{Cu}-\mathrm{SiO}_{2}$ nanoparticles. HDPE composites modified with nanosilica containing immobilized nanosilver or nanocopper were found to be active against E. coli, St. aureus, Salmonella typhimurium, Pseudomonas fluorescens, and Burkholderia cepacia whereas unmodified (without $\mathrm{Ag}-\mathrm{SiO}_{2}$ or $\mathrm{Cu}-\mathrm{SiO}_{2}$ ) did not show this efficacy. Thus silica-filled HDPE composites containing active nanosilver or nanocopper are effective bactericidal materials.

\section{Conflict of Interests}

The authors declare that there is no conflict of interests regarding the publication of this paper.

\section{Acknowledgments}

This work has been financially supported by project no. UDAPOIG.01.03.01-00-073/08-00 cofinanced by EU (European Regional Development Fund). The authors would like to thank MSc Maciej Studziński (Industrial Chemistry Research Institute) for providing DMTA analyses.

\section{References}

[1] A. L. Brody, E. P. Strupinsky, and L. R. Kline, Active Packaging for Food Applications, Technomic Publishing, 2001.

[2] C. Radheshkumar and H. Münstedt, "Antimicrobial polymers from polypropylene/silver composites-Ag+ release measured by anode stripping voltammetry," Reactive and Functional Polymers, vol. 66, no. 7, pp. 780-788, 2006.

[3] J. E. Gray, P. R. Norton, R. Alnouno, C. L. Marolda, M. A. Valvano, and K. Griffiths, "Biological efficacy of electrolessdeposited silver on plasma activated polyurethane," Biomaterials, vol. 24, no. 16, pp. 2759-2765, 2003.

[4] C. Damm, H. Münstedt, and A. Rösch, "Long-term antimicrobial polyamide 6/silver-nanocomposites," Journal of Materials Science, vol. 42, no. 15, pp. 6067-6073, 2007.

[5] S. Goldberg, R. J. Doyle, and M. Rosenberg, "Mechanism of enhancement of microbial cell hydrophobicity by cationic polymers," Journal of Bacteriology, vol. 172, no. 10, pp. 5650$5654,1990$.

[6] Q. L. Feng, J. Wu, G. Q. Chen, F. Z. Cui, T. N. Kim, and J. O. Kim, "A mechanistic study of the antibacterial effect of silver ions on Escherichia coli and Staphylococcus aureus," Journal of Biomedical Materials Research, vol. 52, no. 4, pp. 662-668, 2000.

[7] J. S. Kim, E. Kuk, K. N. Yu et al., "Antimicrobial effects of silver nanoparticles," Nanomedicine: Nanotechnology, Biology, and Medicine, vol. 3, no. 1, pp. 95-101, 2007.

[8] I. Sondi and B. Salopek-Sondi, "Silver nanoparticles as antimicrobial agent: a case study on E. coli as a model for Gramnegative bacteria," Journal of Colloid and Interface Science, vol. 275, no. 1, pp. 177-182, 2004.

[9] J.-M. Lee, D.-W. Kim, Y.-D. Jun, and S.-G. Oh, "Preparation of silica-silver heterogeneous nanocomposite particles by onepot preparation strategy using polyol process: size-controlled immobilization of silver nanoparticles," Materials Research Bulletin, vol. 41, no. 8, pp. 1407-1416, 2006.

[10] K.-Y. Yoon, J. H. Byeon, J.-H. Park, and J. Hwang, "Susceptibility constants of Escherichia coli and Bacillus subtilis to silver and copper nanoparticles," Science of the Total Environment, vol. 373, no. 2-3, pp. 572-575, 2007.

[11] J. P. Ruparelia, A. K. Chatterjee, S. P. Duttagupta, and S. Mukherji, "Strain specificity in antimicrobial activity of silver and copper nanoparticles," Acta Biomaterialia, vol. 4, no. 3, pp. 707-716, 2008. 
[12] G. Ren, D. Hu, E. W. C. Cheng, M. A. Vargas-Reus, P. Reip, and R. P. Allaker, "Characterisation of copper oxide nanoparticles for antimicrobial applications," International Journal of Antimicrobial Agents, vol. 33, no. 6, pp. 587-590, 2009.

[13] M. Zielecka, "Characteristics of silica nanopowders and sol containing immobilized nanoparticles of copper or silver," Polimery, vol. 56, no. 10, pp. 765-768, 2011.

[14] C. Damm and H. Münstedt, "Kinetic aspects of the silver ion release from antimicrobial polyamide/silver nanocomposites," Applied Physics A, vol. 91, no. 3, pp. 479-486, 2008.

[15] J. Davenas, P. Thévenard, F. Philippe, and M. N. Arnaud, "Surface implantation treatments to prevent infection complications in short term devices," Biomolecular Engineering, vol. 19, no. 26, pp. 263-268, 2002.

[16] J.-W. Kim, J.-E. Lee, S.-J. Kim et al., "Synthesis of silver/polymer colloidal composites from surface-functional porous polymer microspheres," Polymer, vol. 45, no. 14, pp. 4741-4747, 2004.

[17] R. Jeziórska, M. Zielecka, A. Szadkowska, Z. Żakowska, and B. Gutarowska, "Effect of silica containing immobilized nanosilver on the structure and selected properties of wood-filled highdensity polyethylene composites," Journal of Biobased Materials Energy, vol. 6, no. 4, pp. 370-379, 2012.

[18] M. Zielecka, E. Bujnowska, M. Wenda et al., "The method for manufacturing nanosilica powders with bactericidal properties, mainly for polymeric composites," Polish Patent Application 390296, 2010, PCT/PL/2011/000008.

[19] M. Zielecka, E. Bujnowska, R. Jeziórska, K. Cyruchin, B. Kępska, and M. Wenda, "The method for manufaturing nanosilica powders with fungicidal properties, mainly for polymeric composites," Polish Patent Application 391169, 2010, PCT/PL/2011/000047.

[20] M. Zielecka, E. Bujnowska, B. Kẹpska, M. Wenda, and M. Piotrowska, "Antimicrobial additives for architectural paints and impregnates," Progress in Organic Coatings, vol. 72, no. 1-2, pp. 193-201, 2011.

[21] R. Jeziórska, M. Zielecka, A. Szadkowska et al., "Polyolefins nanocomposites with bactericidal properties," Polish Patent Applications 399495, 2012.

[22] R. Jeziórska, "Functionalization of low density polyethylene with ricinol-2-oxazoline methyl maleate in a twin-screw extruder," International Polymer Processing, vol. 22, no. 2, pp. 122-131, 2007.

[23] M. Tanahashi, "Development of fabrication methods of filler/polymer nanocomposites: with focus on simple meltcompounding-based approach without surface modification of nanofillers," Materials, vol. 3, pp. 1593-1619, 2010.

[24] R. Jeziórska, B. Świerz-Motysia, M. Zielecka, and M. Studziński, "Polyamide/spherical nanosilica nanocomposites," Polimery, vol. 54, no. 10, pp. 647-656, 2009.

[25] D. B. Bikiaris, A. Vassiliou, E. Pavlidou, and G. B. Karayannidis, "Compatibilisation effect of PP-g-MA copolymer on $\mathrm{iPP} / \mathrm{SiO}_{2}$ nanocomposites prepared by melt mixing," European Polymer Journal, vol. 41, no. 9, pp. 1965-1978, 2005.

[26] M. A. Osman and A. Atallah, "Surfactant chain length and tensile properties of calcium carbonate-polyethylene composites," Macromolecular Chemistry and Physics, vol. 208, no. 1, pp. 8793, 2007.

[27] R. Jeziórska, B. Świerz-Motysia, M. Zielecka, A. Szadkowska, and M. Studziński, "Structure and mechanical properties of low-density polyethylene/spherical silica nanocomposites prepared by melt mixing: the joint action of silica's size, functionality, and compatibilizer," Journal of Applied Polymer Science, vol. 125, no. 6, pp. 4326-4337, 2012.

[28] K. Jordens, G. L. Wilkes, J. Janzen, D. C. Rohlfing, and M. B. Welch, "The influence of molecular weight and thermal history on the thermal, rheological, and mechanical properties of metallocene-catalyzed linear polyethylenes," Polymer, vol. 41, no. 19, pp. 7175-7192, 2000.

[29] R. Benavente, E. Pérez, M. Yazdani-Pedram, and R. Quijada, "Viscoelastic relaxations in poly(ethylene-co-1-octadecene) synthesized by a metallocene catalyst," Polymer, vol. 43, no. 25, pp. 6821-6828, 2002.

[30] K.-H. Nitta and A. Tanaka, "Dynamic mechanical properties of metallocene catalyzed linear polyethylenes," Polymer, vol. 42, no. 3, pp. 1219-1226, 2001.

[31] M. L. Cerrada, R. Benavente, and E. Perez, "Effect of short glass fiber on structure and mechanical behavior of an ethylene-1octene copolymer," Macromolecular Chemistry and Physics, vol. 202, no. 13, pp. 2686-2695, 2001.

[32] M. L. Cerrada, R. Benavente, B. Peña, and E. Pérez, "The effect of thermal treatment on the structure and relaxation processes of olefinic polymers synthesized with metallocene catalysts," Polymer, vol. 41, no. 15, pp. 5957-5965, 2000.

[33] M. L. Cerrada, R. Benavente, E. Perez, and J. M. Perena, "The effect of annealing on the structure and relaxation processes of vinyl alcohol-ethylene copolymers," Polymer Science B: Polymer Physics, vol. 39, no. 1, pp. 1-12, 2001.

[34] R. Popli, M. Glotin, and L. Mandelkern, "Dynamic mechanical studies of $\alpha$ and $\beta$ relaxations of polyethylenes," Journal of Polymer Science B: Polymer Physics, vol. 22, no. 3, pp. 407-448, 1984.

[35] G. Zamfirova, J. M. Pereña, R. Benavente, E. Pérez, M. L. Cerrada, and E. Nedkov, "Mechanical properties of ultra high molecular weight polyethylene obtained with different cocatalyst systems," Polymer Journal, vol. 34, no. 3, pp. 125-131, 2002.

[36] V. Vladimirov, C. Betchev, A. Vassiliou, G. Papageorgiou, and D. Bikiaris, "Dynamic mechanical and morphological studies of isotactic polypropylene/fumed silica nanocomposites with enhanced gas barrier properties," Composites Science and Technology, vol. 66, no. 15, pp. 2935-2944, 2006.

[37] J. L. Way, J. R. Atkinson, and J. Nutting, "The effect of spherulite size on the fracture morphology of polypropylene," Journal of Materials Science, vol. 9, no. 2, pp. 293-299, 1974. 

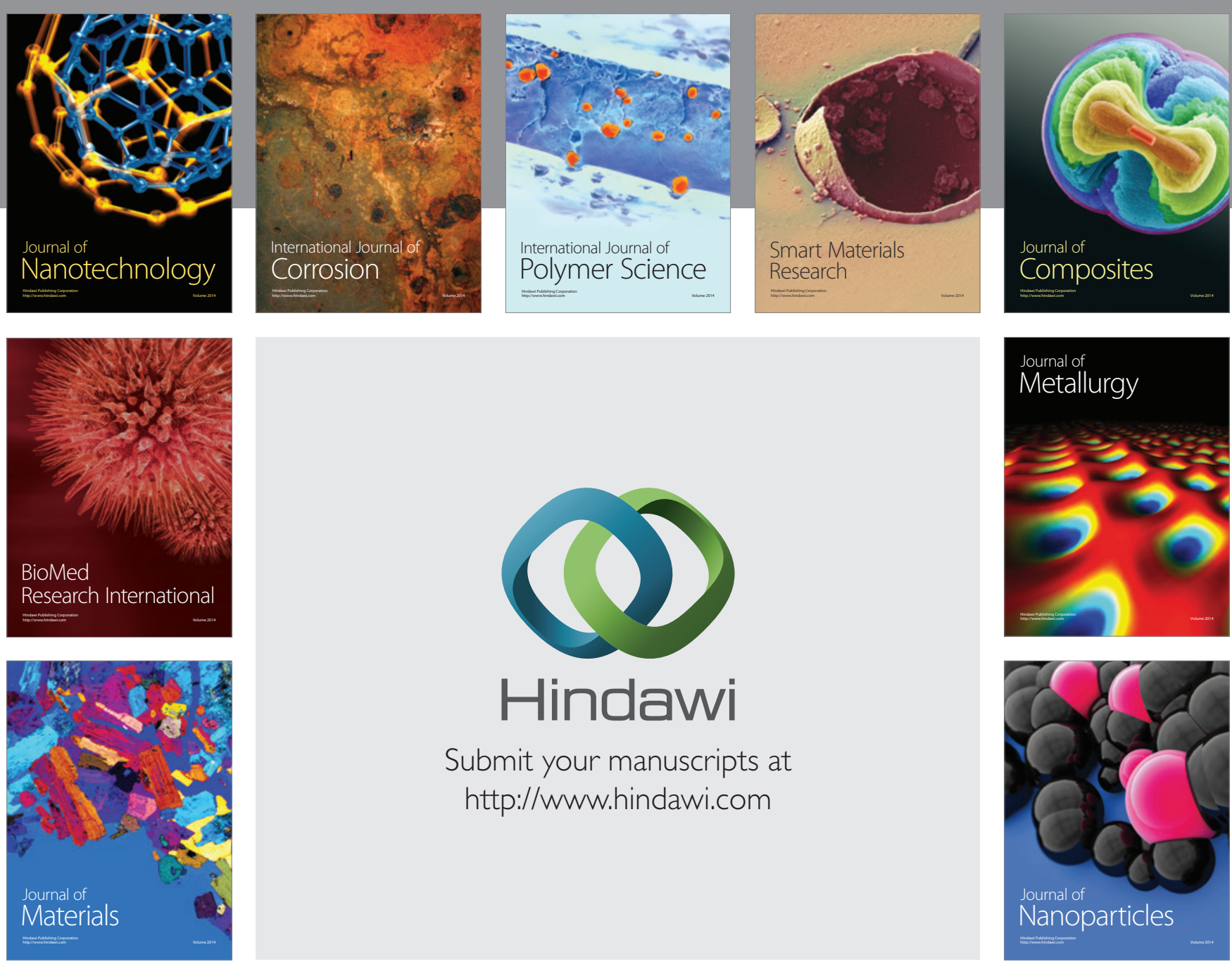

Submit your manuscripts at http://www.hindawi.com
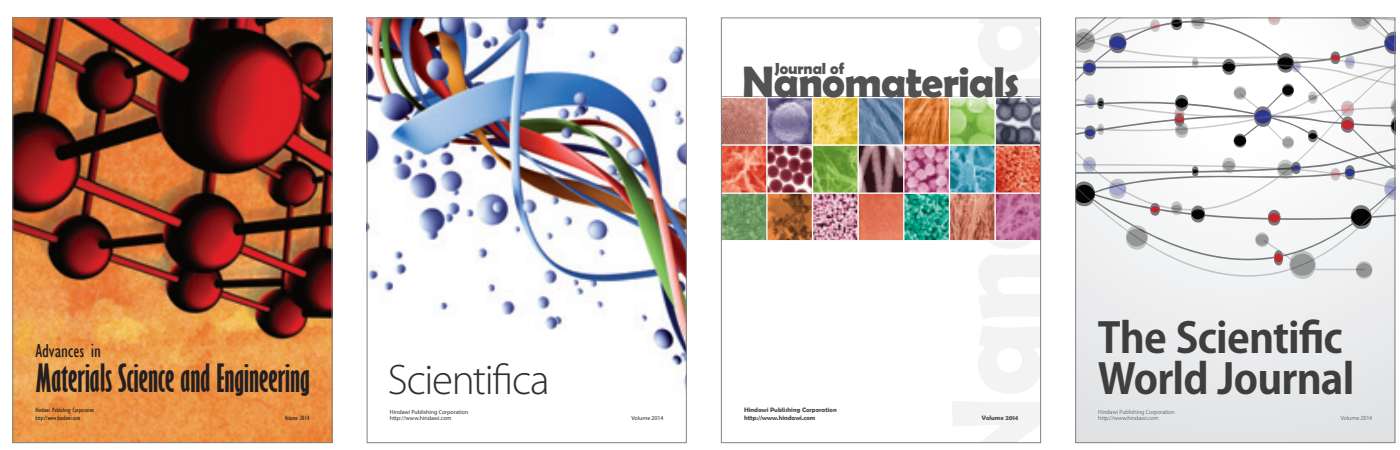

\section{The Scientific World Journal}
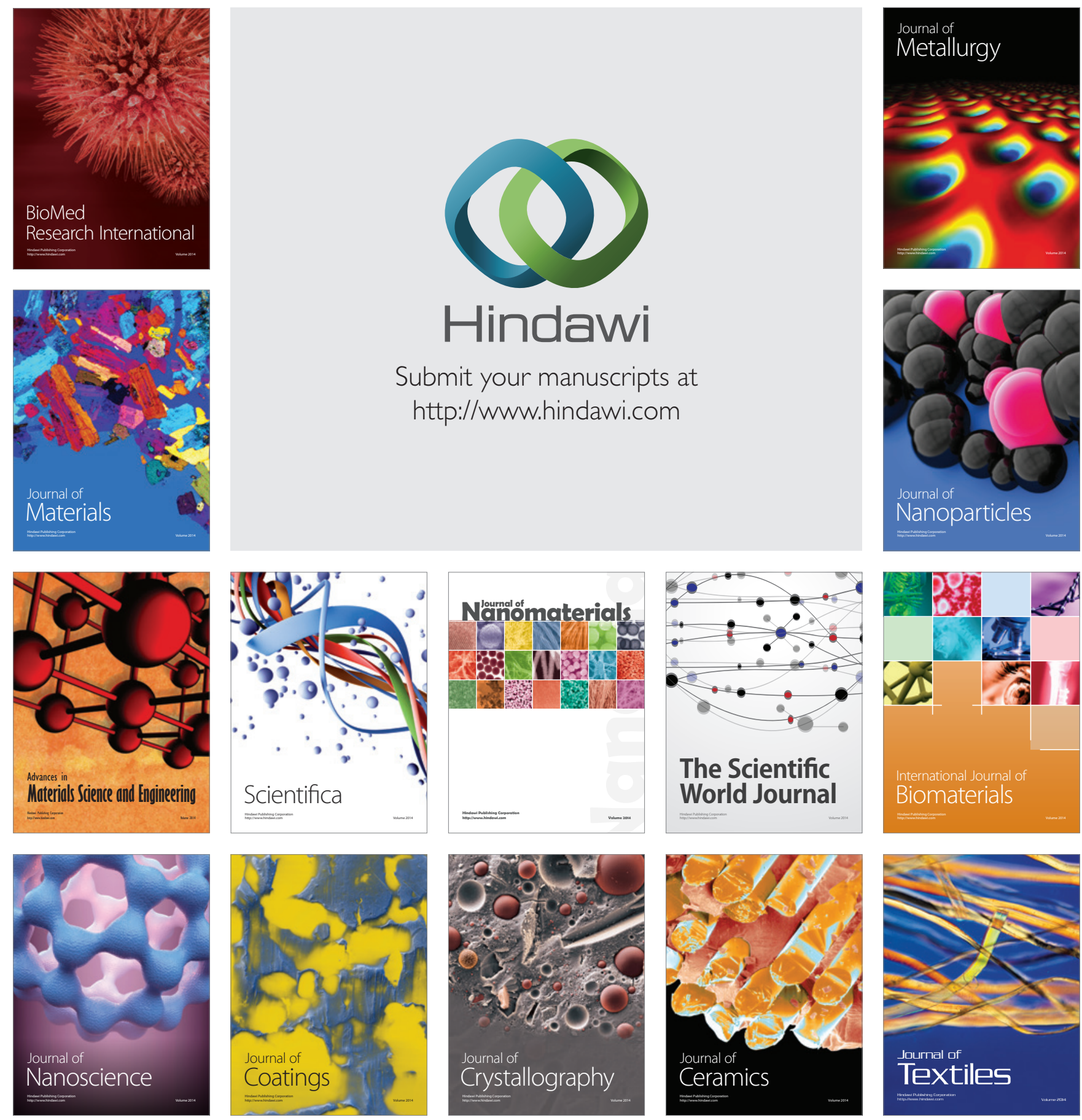